\title{
Will We Wonder Where Development Went, When We Wash Our Minds with Environment?
}

\section{by Brian Johnson*}

"Inevitably the environmental concern will cast $i t s$ shadow on all international economic relations". This was how a group of 27 leading development economists, sociologists and environmental scientists recently summed up the prospect for rich nation / poor nation relations in an environmentally-conscious decade. This Group was brought together last June in Founex, Switzerland by Maurice Strong, Secretary General of the September 1972 United Nations Conference on the Human Environment (the 'Stockholm Conference'). In the course of nine days of debate and discussion, the Founex Group hammered out a policy statement entitled "Development and Environment". 1 This document was intended for the consideration of leaders in developing countries and also for those in industrialised countries who concern themselves with North/South trade and aid.

The Founex Report has been generally well received among leaders of developing countries. Some of the reasons

* Brian Johnson, a Fellow of IDS and of the Institute for the Study of International Organization, is currently undertaking research on the coordination of decision-making in a number of governments in relation to the technical assistance-providing agencies that make up the UN System. He is also a consultant to the Secretary-General of the United Nations ('Stockholm') Conference on the Human Environment, in which capacity he has been involved in the preparation of the forthcoming World Report on the Environment, and in the secretariat's work on the international institutional follow-up required after the Stockholm Conference. Brian Johnson's monograph, "The United Nations System and the Human Environment" was published by the ISIO in October.

"Development and Fnvironment" UN Document GE 71-13738 
for this reception become immediately apparent on reading the Report, which is as remarkable for what it leaves out as for what it contains. The experts have nothing to say, for example, on the central problem of population growth or its relationship to the availability of natural resources. The fact that developing country panelists avoided discussion of their own population problems is understandable in view of the attention now given to this topic in other forums. Perhaps they cannot be blamed, either, for failing to consider, or indeed even refer to, the relationship of rich nations' population growth and increasing resource-consumption and the effect that this must have on the 'carrying capacity' of the planet's natural systems. It was probably inevitable that they avoid any entanglement in this $\$ 64$ question that faces all theorists and practitioners of development and environment: Is indefinite economic expansion a feasible credo for all -- or even part of -- genus homo sapiens?

Since the Founex meting, however, the message of environmental doomsmen has provoked some official salvos from developing country spokesmen. Probably the most notable counter-attack so far has come from Brazil. Ambassador Frazao, Brazil's Permanent Representative to the United Nations, concluded a powerful statement before the Second Committee of the General Assembly last October 9 th, with the words "God forbid that I be unjust, but it appears to me that in some quarters the intention seems to be not only as in the past to justify apathy towards iniquity; it is also to go one step, indeed many steps further, so as to methodically characterise the development of developing countries as a major threat to environment and thereby as a serious danger to mankind".

\section{ENVIRONMENT: THE RIVAL PRIORITY}

The developing countries' leadership has plenty of grounds for anxiety. In most developed Western countries it is now widely accepted that the idea of somehow closing the famous 13 -fold gap between developed and developing country average per capita incomes is out of date: a pious post-colonial hope that is now, even if desirable, unrealisable in view of anticipated world population growth and future resource demands of the rich 
nations. 1 But the real incubus over the less developed countries is the fact that cleaning up pollution of urban industrial environments represents a rival spending priority whose intellectual basis is seen by many as actually opposing the development ethic. The rationale for 'benign neglect' of developing countries fits into the same handy intellectual package as an alternative priority.

There is then the prospect that right and left wing opponents of the aid relationship between rich and poor countries may be joined by a youthful and vociferous group of environmental enthusiasts who would otherwise support aid from the viewpoint of the political centre. Such an uncoordinated but solid phalanx of opposition could quite possibly succeed in bringing all official British and American aid of any significance to an end within the present decade. Yet in sober political judgement, any such cleancut result would seem highly unlikely. The threat to aid will continue to come from the traditional left and right, neither of which group is much impressed by appeals for more environmental caution. It would be inconsistent, however, with an ecologically-oriented outlook to advocate acceptance of a widening income gap between rich and poor nations. Indeed it is noteworthy in this connexion that almost all the doom prophets and proponents of the 'stable state' societies lay stress on the need for massive transfers of resources in favour of the Third World populations, as Paul Ehrlich says, to make possible world-wide 'semi-development'. That they should do so is, of course, consistent with their whole philosophy of the need to seek balance and equilibrium in man's relationship with nature and therefore also with his own kind. The problem presented by the doomsday preachers is not that they themselves preach international economic inaction or reaction, but that a serious lack of balance and 1 It is not, of course, widely realized that the United States alone currently consumes one quarter of the world's output of fertilizer and steel, $40 \%$ of wood pulp, $36 \%$ of fossil fuels, a fifth of its cotton, and, -- most significantly -- $10 \%$ of the output of the world's total farmlands outside their own territory. Popular awareness of the resource-pressure problem is probably much more the result of widespread awareness of projections of future population -- sheer number -- rather than of what specific resources these numbers will need if they are to 'modernize'. 
moderation in their message alerts the public to only one aspect of their argument.

EXPORTING POLLUTION: WHAT TERMS FOR DIRTY MONEY?

The real danger that environmental concern in the rich world presents to developing countries stems from more practical and short-term considerations of public policy. With or without the environment priority as a rival attraction, it is not hard to envisage a number of Western Presidents and Premiers shifting towards Edward Heath's declared strategy regarding the ' 1 per cent (of GNP) aid target' in the hope that the $1 \%$ pledge may be redeemed via private foreign investment. A new impetus in this direction could well be the attractiveness of relocating polluting industry in the Third World. Were this to occur, one can scarcely imagine a colateral offer of 'discounts for destruction' caused to ecologically delicate environments.

The case of Singapore is almost certainly a straw in the wind. As a tiny island-city-state, Singapore has perforce adopted drastic measures for the protection of $i$ ts water and urban amenities. Yet its Government has recently welcomed into its midst large-scale investment by some of Japan's dirtiest metal processing industries. Singapore's dilemma is likely to become a familiar one among developing countries experiencing an appalling escalation of urban unemployment, together with stagnant foreign exchange earnings.

The scale of this problem can still only dimly be perceived. The Founex report favoured a compromise position between an unabashed welcoming of 'dirty' new investment by developing countries whose natural resource endowment gave them a potential comparative advantage, and a view that redistribution of pollution cannot be accepted as even an interim solution to the overall problem of environmental despoliation. There are already signs that the panel's proposal on this problem may come to be accepted as a broad policy guideline by many developing countries faced with this dilemma. The Founex meeting maintained that:

"...industries which may be regarded as pollutive in some advanced countries because of their more limited environmental carrying capacity may well not be pollutive, or much less so, in the context of the developing countries with much less environmental pollution at present. Secondly, environmental standards and costs are likely to be quite 
different from developed to the developing world so that the developing countries may still possess comparative advantage in some of these industries despite the adoption of certain environmental controls in conformity with their own requirements. Thirdly, there is no reason why the developing countries should permit foreign investment, which comes to their countries into pollutive industries, to escape more stringent environmental standards back home if it results in a high rate of remittance of profits and even a lower net transfer of resources. In any arrangement that is made, it must be ensured that (a) foreign investment is on favourable terms and conditions, (b) it adds to the net transfer of resources, and (c) it conforms to the environmental standards that the recipient country wishes to impose in the light of its own stage of development and its own cultural and social objectives. So long as these safeguards are provided, there is no reason why the developing countries should not increasingly specialize in certain industrial fields, both for home market production and export purposes, which are going to become more costly for the developed world because of their growing concern with environmental standards".

\section{THE PROSPECT OF 'ENVIRONMENT BARRIERS'}

Serious as it is, however, the prospective impact of environmental concern on foreign investment is not likely to be seen for some time to come. A much earlier threat is presented by the potential vicious circle of environmental concern and threatening industrial over-capacity in the rich countries. The emerging rich-nation trading blocks of the 1970 s face mounting protectionist pressures as the classic spectres of inadequate market bases and threatening over-capacity return to haunt their post-Keynesian economies. Governments that have pinned their hopes for controlled economic expansion on consumer demand management are realising that their art has little power in the absence of any real management of the technology supply. Within rich countries, the increasing regional inequities and unemployment produced by socially unaware technology, encourage governments to give the protectionist screw another turn. As they do so, 'environment' offers them a whole new armoury of non-tariff devices for protecting

1

Op. cit. para 4.16 
their more ailing and polluting industries. Several developing countries already have grounds for dreading the impact of this new potential 'plague of Egypt'. In 1969, for example, the Peruvian and Philippine tuna fishing industries were struck crippling blows by the revision of official US standards on mercury content of tuna fish.

Developing countries are also bracing themselves for a general raising of developed countries' export prices as a result of the imposition of pollution controls by their Governments. The earliest impact is foreseen on some agricultural products and on chemicals. There is also, of course, the danger that specific appeals by organized lobbies of import-competing industries may become generalised. The Founex Panel's report dwelt at length on the danger that humanitarian concern for the protection of environments may become allied with protectionist pressures to oppose the concept of 'sweated environments'. The import of fruits and vegetables carrying traces of DDT has already been banned by certain European countries. Dairy products, fish, meat, fruits and many vegetables are all susceptible to the imposition of high environmental standards by developed countries. The Founex report calls for action to cushion the disruptive effects of such measures on the trade of developing countries through a system of prior consultation and advance warnings by the developed countries contemplating such action. Study of the possibility of channeling additional aid for the adaptation of affected export industries by developing countries or the diversification of exports to avoid such environmental impacts is also called for. At the same time, however, distinction is made in the report between concern for the quality of a product and the quality of the environment in which the product was produced. But the difficulties of establishing such distinctions under the heat of protectionist pressures are obvious.

A clearer distinction is possible in the case of the displacement of exports of developing countries, such as high sulphur fuel or lead, through technological advance. Such changes are clearly inseparable from the general trend of import substitution. The recycling of raw materials will inevitably reduce demand in the short or medium term for some developing countries' primary exports. Here again, the Founex experts call for 
anticipatory studies of threats to exports, the development of an early warning system and the institution of measures to help seriously affected countries to restructure their investment, production and exports.

As regards the impact of environmental concerns on the overall expansion of international trade, similar procedures for prior notification, consultation and coordination are clearly also desirable. The apparently inexorable advance of a common European sense of bloc interest and bloc power in international trade and payments is already being complemented by environmental activity. The Commission of the European Communities is currently preparing, under the direction of Dr. Altiero Spinelli, a programme of negotiations (explicitly, standards of health, safety, etc.) among the ten prospective members of an enlarged community, in addition to pressing towards the more familiar objectives of new systems of fiscal standardization, trade preferences, etc. The evidence is mounting that 'vulnerable' European polluters will seize 'environment' as a peculiarly handy weapon of international self-defence. Nor have the sounds of protectionist axe-grinding been absent from ostensibly environmental discussions on product performance standards in the United States, notably in the motor industry.

Such activities on both sides of the Atlantic are being monitored through newly-established environmental committees and secretariats in NATO and the OECD. They have also been raised in the GATT where the suggestion has been made that environmental controls should feature prominently among the ongoing negotiations over nontariff barriers. The problem with the use of GATT machinery is the glacial pace of negotiations in this wide-membership body. If the present pace of GATT progress on non-tariff negotiations is maintained for environmental issues, it is almost certain that groupings of GATT members will, in the meantime, work out joint negotiating positions which would be almost impossible to re-negotiate in the course of GATT proceedings, and which would thus reduce the progress of such talks to a complete standstill. At present, however, the likely dimensions of environmental trade-barrier problems are not at all clear. The Founex group's call for research to define further the problem and amass much more concrete information is clearly timely. UNCTAD is already conducting studies on aspects of this problem. FAO has also produced most useful work on food standards 
considerations, including contamination problems. The Founex group calls on FAD to expand these and also to establish agreed world standards and guidelines for export of foodstuffs. It also calls on the GATT to monitor the rise of non-tariff barriers on grounds of environmental concern and to stress such trends heavily in its Annual Reports.

TRADE AND AID WITH ENVIRONMENT STRINGS

In the Preparatory Committee meetings for the Stockholm Conference, considerable anxiety has been expressed by all developing countries at the possible impact of donor countries imposing their own environmental concerns excessively in the establishment of aid priorities and in project appraisal. By their very nature, environmental diseconomies are terribly difficult to measure or quantify. Widely differing judgements are frequently made as to the time period over which such diseconomies may occur in specific projects, and over their degree of reversibility. Delays in project processing by the World Bank resulting from environmental preoccupations have already occurred in the case of hydro-Dower and river basin development projects. These may become further protracted by recipient countries' resistance to the imposition of detailed guidelines for environmental appraisal. Their determination to avoid the imposition of arbitrary guidelines and further project delays will inevitably add to recipient countries' interest in shifting aid from a project to a programme basis, but it will raise new objections on the part of the international financing institutions.

The type of technology transferred to developing countries will, in the coming years, be increasingly affected by environmental concern. The danger is clearly present that the orientation of industrialised countries' research and development towards emphasis on non-pollutive technology may produce technological transfers to developing countries that are even more inappropriate to their problems than is often the case at present. There is also the problem of additional cost. Estimates ranging from five to twenty per cent have been offered as to the likely increase in costs occasioned by incorporation of pollutioncontrolling techniques. Once again very little specific information is available, and the Founex grous call for urgent examination by the United Nations Advisory Committee on Science and Technology. The impact of such increased costs on the real value of resource flows should also be 
reparted on by the Development Assistance Committee of the OECD.

Finally, dominating all of the other immediate environmental considerations that shadow rich/poor nation economic relations, is the question: Who pays for the higher cost of more environmentally sensitive economic development of the Third World? This is the hard and irreducible rock on which the attempted environmental dialogue could well founder. The price of developing country cooperation in the Stockholm exercise has been inclusion in the Conference's agenda, not only of the 'development environment' issue, but of a number of aspects of 'environmental improvement' which have hitherto been subsumed under the heading of development. Item one, in fact, of the Stockholm Agenda is "The Planning and Management of Human Settlements for Environmental Quality". Under this item is included the whole question of comprehensive development planning, including housing, water supply, sewage and waste disposal, human health and welfare factors, transport and communications, as well as industry, population growth and distribution, recreation and leisure, and social, cultural and aesthetic factors.

\section{DEVELOPMENT AND ENVIRONMENT: THE SIAMESE TWINS}

There is, of course, the danger that such a formulation of the international environment problem will result in a shopping 1 ist of 'action proposals' so widely scattered and costly that nothing concrete or tangible will result from the new environmental focus of international problems of which the name 'Stockholm' is the symbol. Notwithst anding their acceptance of wide development/environment overlap for domestic purposes (Peter Walker, Britain's Secretary of State for the Environment went on record recently as saying that his department was just as much concerned with our historic slums as with our historic buildings) the British and other governments are in no mood to call the international development spade by any other name.

Yet despite the tensions and the trade-off bargaining which will occupy governments at Stockholm next summer, development and environment will remain, as they have always been, Siamese twins. Both risk bleeding to death if they are sundered. Developing countries have a long way to go in realising that at little or no cost to their social objectives, they may secure their development 
over time by far more careful attention to the needs of nature. In this regard, comparisons with the devil-may-care past development of the industrialised countries are exceedingly misleading. Yet another of the tragic handicaps of many of the developing regions is the far greater susceptibility of tropical and subtropical environments to damage by thoughtless development.

It must also be remembered that many of those developing country leaders who protest most vociferously at environmental interference with their development projects will be those individuals prepared, like the factory owners of early industrial England, to rape their environment at the expense of the masses whose cause they claim to espouse, and move on with their profits to fresh (and probably foreign) pastures.

On the industrial countries' side of the rich/poor nation relationship, environmental concern has one hazy but potentially great advantage. It could conceivably encourage the complex parts of fisiparous societies to see the impact of their relations with the Third World as a unity and to realise that the change which environmental concern may bring in 'developed' or 'overdeveloped' societies will, for better or worse, be a major, perhaps an overriding, precondition for future change in the Third World. 